\title{
Acute Kidney Injury Secondary To Snake Bite In Patients Presenting To A Tertiary Care Hospital
}

Harish Kumar, Adnan Bashir, M Omer Sultan, Khadijah Abid, Nabeel Naeem Baig

ABSTRACT

Objective: To determine the frequency of Acute kidney injury secondary to snake bite in patients presenting to a tertiary care hospital.

Subject and Methods: This was a descriptive cross-sectional study conducted at the department of General Medicine, Jinnah postgraduate medical center, Karachi, from $10^{\text {th }}$ June 2015 to $10^{\text {th }}$ Jan 2016. Patients with diagnosis of snake bite were enrolled. Detailed history, physical examination and biochemical measurements were recorded. Patients underwent serum creatinine levels for diagnosis of AKI.

Results: One hundred and twelve patients fulfilling the inclusion criteria were included in this study.There were 90 (83.36\%) males and 22 (19.64\%) females. The mean \pm standard deviation age of study population was $28 \pm 0.151$ years. On analysis of risk factors it was observed that 33 (29.46\%) patients were obese. On analysis of outcome variable, it was observed that $33(29.46 \%)$ had AKI.

Conclusion: Around $30 \%$ of patients who developed AKI were presented with history of snake bite. However, factors such as age, gender, duration and obesity were not related with the AKI.

Key words: AKI, Snake bite, kidney, CRF, renal shut down.

\section{INTRODUCTION:}

Snake bite remains major public health problems worldwide and it has been estimated that in Asia alone, there are approximately four million cases per year of snake bites, of which approximately venomous snake bites account for approximately $50 \%$ of the cases with about 100,000 annual deaths ${ }^{11}$.

Snake bite is primarily a problem of the poorer rural populations involving mainly farmers ${ }^{2}$ and snake bites are not systematically reported, only very few countries possess a reliable epidemiological data on snake bites. Most of the available data are based on hospital statistics, which constitute a very small percentage of cases of snake bite ${ }^{3,4}$. Incidence and frequency of snake bite vary in different geographic regions, depending on several factors like climate, ecology, biodiversity, distribution of snakes and human density ${ }^{5}$.

rーーーーーーーーーーーーーーーーーー

I Harish Kumar

I FCPS II Trainee,

Jinnah Post Graduate Medical Center, Karachi

I Adnan Bashir

Assistant Professor,

Hamdard College of Medicine and Dentistry

I

M Omer Sultan

Senior Registrar

I Jinnah Post Graduate Medical Center, Karachi

I Khadijah Abid

I Senior Statistician, College of Physicians \& Surgeons Pakistan |

I Email:khadijahabid@gmail.com

I Nabeel Naeem Baig

Senior Executive Officer Research,

College of Physicians and Surgeons Pakistan

Received: 10-06-18

Accepted: $24-07-18$
The mortality rate form snake bite is low, ${ }^{6}$ and if the victim is treated without losing too much time, this mortality is potentially preventable $e^{1,7,8}$. In a study from Malaysia, it was recognized that the majority of the snake bite cases were due to non-venomous snakes, but the venomous bites were the cause of significant morbidity and mortality9.

Prevalence of Acute renal failure or acute kidney injury secondary to snake bite ranges from $1 \%$ to $30.96 \%{ }^{10-16}$. However in pediatric age group ( $<18 \mathrm{yrs}) 18.7 \%$ of patients developed snake bite induced acute kidney injury ${ }^{17}$. et al. also reported that acute renal failure patients were younger. Out the 19 children ( $=12$ years), 11 developed acute renal failure (58\%) and out of the 81 adults, 18 developed acute renal failure $(22 \%)^{18}$.

The rationale of study is that the studies on the subject under consideration are scarce in Pakistan and secondly most of the studies done on retrospective data. Therefore present study was designed to assess the current and actual magnitude of the problem, thereby strategies could be devised for resource allocation and for prompt management to decrease the morbidity of AKI and mortality.

\section{SUBJECTS AND METHODS:}

This was cross-sectional study conducted at the Department of General Medicine, Jinnah postgraduate medical centre, Karachi, from $10^{\text {th }}$ June 2015 to $10^{\text {th }}$ Jan 2016. The sample size was calculated by using WHO sample size calculator, based on frequency of AKI in snake bite cases $=20.48 \%{ }^{14}$, margin of error as $7.5 \%, n=112$ patients with snake bite. Non-probability consecutive sampling was done. All patients of 25 to 60 years of age of either gender with snake bite diagnosed presenting within 12 hours of incident were included in the study. Patients with documented history for 
a pre-existent renal disease (Serum creatinine of $>1.5 \mathrm{mg} / \mathrm{dL}$ ), bilateral small kidneys, loss of the corticomedullary differentiation, obstructive nephropathy or other renal pathologies, diagnosed cases of hypertension/diabetes mellitus \& exposure to nephrotoxic drugs/toxins on history and verified by physicians prescription were excluded from the study.

Approval from ethical review committee was sought prior to conduct of the study. Patients meeting the inclusion criteria admitted in the department of Medicine, Jinnah Postgraduate Medical Center, Karachi were enrolled in the study. The purpose procedure, risk and benefits of the study were explained before taking informed consent. Researcher took brief history for duration of snake bite and demographics. Baseline investigations including creatinine were sent to the laboratory at the time of admission. Serum creatinine level was repeated after 48 hours and rise in the serum creatinine concentration of $=0.3 \mathrm{mg} / \mathrm{dL}$ from baseline value within 48 hours was taken as AKI. These findings along with the demographic data were recorded in proforma.

\begin{tabular}{|l|l|}
\hline Variables & Frequency (\%) \\
\hline $\begin{array}{l}\text { Gender } \\
- \text { Male } \\
- \text { Female }\end{array}$ & $\begin{array}{l}90(80.36 \%) \\
22(19.64 \%)\end{array}$ \\
\hline Age in years $(M e a n \pm S D)$ & $28 \pm 0.151$ \\
\hline BMI (Mean \pm SD) & $27.65 \pm 5.393$ \\
\hline $\begin{array}{l}\text { Duration in hours } \\
\text { (Mean } \pm \text { SD) }\end{array}$ & $5.401 \pm 3.367$ \\
\hline $\begin{array}{l}\text { Obesity } \\
\text { - Obese } \\
\text { - Non-Obese }\end{array}$ & $33(29.46 \%)$ \\
\hline
\end{tabular}

Table I: Descriptive Statistics of Study Variables

\begin{tabular}{|l|l|l|l|}
\hline \multirow{2}{*}{ Variables } & \multicolumn{2}{|c|}{ AKI } & \multirow{2}{*}{ P-value } \\
\cline { 2 - 3 } & YES & NO & \\
\hline $\begin{array}{l}\text { Gender } \\
\text { - Male }\end{array}$ & 26 & 64 & \\
- Female & 7 & 15 & 0.487 \\
\hline Age group & & & \\
- 3-32 Years & 17 & 53 & 0.091 \\
\hline 33-61 Years & 16 & 26 & \\
\hline $\begin{array}{l}\text { Duration } \\
\text { Less than 6 hours }\end{array}$ & 22 & 58 & \\
6 hours and above & 11 & 21 & 0.302 \\
\hline $\begin{array}{l}\text { Obesity } \\
\text { - Yes }\end{array}$ & 10 & 23 & \multirow{2}{*}{ No } \\
\hline
\end{tabular}

Table 2: Stratification of Aki W.R.T Effect Modifiers
All the data were analyzed through Statistical Package for Social Sciences (SPSS) version 16. All quantitative variables were presented as mean and standard deviation while qualitative variables were presented as frequency and percentages. Chi square test was applied with $95 \%$ confidence interval $\&$ p-value $=0.05$ was taken as significant.

\section{RESULTS:}

One hundred and twelve patients fulfilling the inclusion criteria were included in this study.

There were 90 (83.36\%) males and 22 (19.64\%) females. The mean \pm standard deviation age of study population was $28 \pm 0.151$ years. On analysis of risk factors it was observed that $33(29.46 \%)$ patients were obese. (Table I)

On analysis of outcome variable, it was observed that 33 (29.46\%) had AKI (Fig I).

Stratification of age, gender, obesity and duration of snake bite is mentioned in (Table II).



Figure I: Frequency of AKI

\section{DISCUSSION:}

We observed that $29.46 \%$ snake bite victims developed AKI. The rate of AKI following E. carinatus or Russell's viper bite is ranging from 13 to $32 \%$ in India ${ }^{19,20}$. In a study conducted by Patil et $\mathrm{al}^{21}$ showed that in the cases of snake bite AKI developed was in $20.48 \%$, whereas in another study by Ali et al., ${ }^{22}$ observed that $17 \%$ cases of snake bite were get complicated by AKI. Different authors have showed the relationship of AKI with snake bite and its correlation with various coagulation disturbances and the subsequent course of these patients in terms of mortality.

We calculated the mean age of patients as $28 \pm 0.151$. The difference was statistically insignificant between those 332 years and 33-61 years. However, Athappan et al. ${ }^{23}$ found that $39.1 \%$ of AKI patients were belong from of older age than non-AKI patients $(35.4 \%)$ and showed statistical significance ( $p$-value $=0.03$ ). In our study the proportion is higher in males, may be due to the fact that men typically go daily in the fields, are more active at night, travel wider, while women for the most of the time, stay in and around 
houses and compounds. In a study by Kulkarni et al., ${ }^{24}$ showed 633 cases, out of which $433(68.40 \%)$ were males who developed AKI while 200 (31.60\%) were females. Bawaskar et al. ${ }^{25}$ observed 182 cases of AKI out of which $114(63 \%)$ were males and 68 (37\%) were females.

In our study mean duration of snake bite was $5.401+3.367$ hours. There was no difference in outcome between those who presented early than late. A similar study showed that bite to needle time greater than two hours was an independent risk factor for the development of AKI $(\mathrm{OR} 2.10, \mathrm{P}=0.001){ }^{23}$ In a study by Kalantri et al. ${ }^{26}$ showed that mean bite to hospital time of $6.5 \pm 10.3$ hours. However, Danis et al. ${ }^{27}$ in his study observed that there was no significant relationship between snake bite and hospital time with development of AKI. The bite to hospital time changes relying upon the availability of medical staff, facilities and the settings in which the study has been done. Anti-snake venom treatment should be neutralized as soon as possible because it is responsible for almost all of the complications related to snake bite. This fact is well supported by different studies which show a direct relation between increasing rates of complications or mortality with late arrival to hospital.

In general mortality because of venomous snake bites is $19.57 \%$, with a significantly higher rate of mortality in victims who developed AKI. A study conducted by Kularatne, ${ }^{28}$ found that out of 336 cases the mortality was observed in $2.6 \%$ patients only. In another study by Kulkarni et al., ${ }^{24}$ the mortality rate was observed in $5.2 \%$ patients. A total of 1548 cases were studied by Athappan et al., ${ }^{23} 159$ patients developed AKI, out of which 36 got expired. Thus, mortality rate described in various studies varies starting with $2.5 \%$ to $25 \%$. The studies involving vipers showed the higher rate of mortality, with higher proportion of patients developing complications. It might have been also intriguing to see that treatment with dialysis was not associated with improved results in patients with snake bite induced AKI . Paul $\mathrm{J}$ et al. ${ }^{29}$ found incidence of acute kidney injury as $43.27 \%$ among 171 snake bite patients. The relationship of snake bite to hospital time with development of AKI highlights the importance of early treatment. The mortality rate of $15.5 \%$ found by Patil et $\mathrm{al}^{21}$ because of snake bite induced acute kidney failure. In another study by Kalantri et al. showed that mortality of $11 \%$ due to venomous snake bite $^{26}$.

\section{CONCLUSION:}

Around $30 \%$ of patients who developed AKI were presented with history of snake bite. The main risk factors for development of AKI in snake bite are older age and prolong bite to hospital time.

\section{REFERENCES:}

1. Patil VC, Patil HV, Patil A, Agrawal V. Clinical Profile and outcome of envenomous snake-bite at tertiary care centre in western Maharashtra. Int J Med Public Health 2011;1:28.
2. Mohapatra B, Warrell DA, Suraweera W, Bhatia P, Dhingra N, Jotkar RM, et al. Snakebite mortality in India: A nationally representative mortality survey. PLoS Negl Trop Dis. 2011;5:e1018.

3. Meenatchisundaram S, Michael A. Snake bite and therapeutic measures: Indian scenario. Indian Journal of Science and Technology 2009;2:69-73.

4. Brunda G, Sashidhar R. Epidemiological profile of snake-bite cases from Andhra Pradesh using immunoanalytical approach. Indian J Med Res. 2007;125:661-8.

5. Cesaretli Y, Ozkan O. Snakebites in Turkey: epidemiological and clinical aspects between the years 1995 and 2004. J Venom Anim Toxins incl Trop Dis. 2010;16(4):579-86.

6. Sharma SK, Khanal B, Pokhrel P, Khan A, Koirala S. Snakebite-reappraisal of the situation in Eastern Nepal. Toxicon 2003;41:285-9.

7. Monteiro F, Kanchan T, Bhagavath P, Kumar G, Menezes R, Yoganarasimha K. Clinico-epidemiological features of viper bite envenomation: A study from Manipal, South India. Singapore Med J 2012;53:203-7.

8. Ahmed SM, Nadeem A, Islam MS, Agarwal S, Singh L. Retrospective analysis of snake victims in Northern India admitted in a tertiary level institute. J Anaesthesiol Clin Pharmacol. 2012;28:45-50.

9. Chew KS, Khor HW, Ahmad R, Rahman NH. A five-year retrospective review of snakebite patients admitted to a tertiary university hospital in Malaysia. Int J Emerg Med. 2011;4:16.

10. Hayat AS, Khan AH, Shaikh TZ, Ghouri RA, Shaikh N. Study of snake bite cases at Liaquat University Hospital Hyderabad/Jamshoro. 2008;20(3):125-7.

11. Kumar MR, Prasad MV, Babu PR, Kumar SS, Subrahmanyam BV, Rammohan P, et al. A retrospective review of snake bite victims admitted in a tertiary level teaching institute. Ann Afr Med. 2014;13:76-80.

12. Danis R1, Ozmen S, Celen MK, Akin D, Ayaz C, Yazanel O. Snakebite-induced acute kidney injury: data from Southeast Anatolia. 2008;30(1):51-5.

13. Harshavardhan L, Lokesh AJ, Tejeshwari HL, Halesha BR, Metri SS. A study on the acute kidney injury in snake bite victims in a tertiary care centre. J Clin Diagn Res. 2013;7(5):853-6.

14. Chadban sj, briganti em, kerr pg, dunstan dw, welborn ta, zimmet pz, et al. Prevalence of kidney damage in australian adults: the ausdiab kidney study. J am soc nephrol $2003 ; 14: 131-8$.

15. Coresh j, astor bc, greene t, eknoyan g, levey as. Prevalence of chronic kidney disease and decreased kidney function in the adult us population: third national health and nutrition examination survey. Am j kidney dis 2003; 41:1-12.

16. Levy as, eckardt ku, tsukamoto $y$, levin a, coresh $\mathrm{j}$, rossert $\mathrm{j}$ etal. Definition and classification of chronic kidney disease: a position statement from kidney disease improving global outcome (kdigo). Kidney int. 2005; 67:2089-100.

17. Mukhopadhyay P, Mishra R, Mukherjee D, Mishra R, Kar M. Snakebite mediated acute kidney injury, prognostic predictors, oxidative and carbonyl stress: A prospective study. ýIndian J. Nephrol. 2016;26(6):427-33.

18. Pinho FMO, Zanetta DMT, Burdmann EA. Acute renal failure after Crotalus durissus snakebite: A prospective survey on 
100 patients. Kidney Int. 2005;67:659-67.

19. Monteiro FN, Kanchan T, Bhagavath P, Kumar GP, Menezes RG, Yoganarasimha K. Clinico-epidemiological features of viper bite envenomation: A study from Manipal, South India. Singapore Med J. 2012;53:203-7.

20. Lavonas EJ, Tomaszewski CA, Ford MD, Rouse AM, Kerns WP., 2nd Severe puff adder (Bitis arietans) envenomation with coagulopathy. J Toxicol Clin Toxicol. 2002;40:911-8.

21. Patil TB, Bansod YV. Snake bite-induced acute renal failure: A study of clinical profile and predictors of poor outcome. Ann Trop Med Public Health. 2012;5:335-9.

22. Ali G, Kak M, Kumar M, Bali SK, Tak SI, Hassan G, et al. Acute renal failure following echis carinatus (saw-scaled viper) envenomation. Indian J Nephrol. 2004;14:177-81.

23. Athappan G, Balaji MV, Navaneethan U, Thirumalikolundusubramanian P. Acute renal ailure in snake envenomation: A large prospective study. Saudi J Kidney Dis Transpl. 2008;19:404-10.
24. Kulkarni ML, Anees S. Snake venom poisoning: Experience with 633 cases. Indian Pediatr. 1994;31:1239-43.

25. Bawaskar HS, Bawaskar PH, Punde DP, Inamdar MK, Dongare RB, Bhoite RR. Profile of snakebite envenoming in rural Maharashtra, India. J Assoc Physicians India. 2008;56:88-95. [PubMed]

26. Kalantri S, Singh A, Joshi R, Malamba S, Ho C, Ezoua J, et al. Clinical predictors of in-hospital mortality in patients with snake bite: A retrospective study from a rural hospital in central India. Trop Med Int Health. 2006;11:22-30.

27. Danis R, Ozmen S, Celen MK, Akin D, Ayaz C, Yazanel O. Snakebite-induced acute kidney injury: Data from Southeast Anatolia. Ren Fail. 2008;30:51-5.

28. Kularatne SA. Common krait (Bungarus caeruleus) bite in Anuradhapura, Sri Lanka: A prospective clinical study, 199698. Postgrad Med J. 2002;78:276-80.

29. Paul J, Dasgupta S. Early Prediction of acute kidney injury by clinical features of snakebite patients at the time of hospital admission. N Am J Med Sci. 2012;4:216-20. 